Laboratoire de Recherche en Gestion

$\&$ Economie

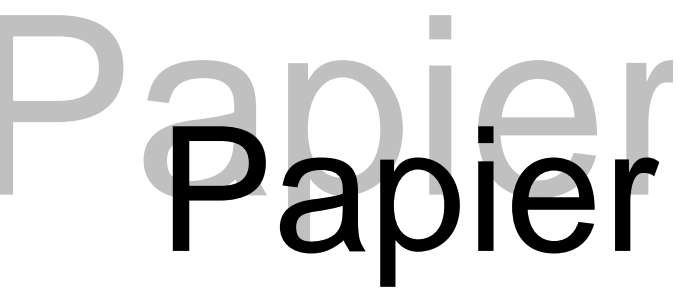

$\mathrm{n}^{\circ} 2008-10$

Collateral and Adverse Selection in Transition Countries

Laurent Weill / Christophe J. Godlewski

Avril 2008

Faculté des

sciences économiques

et de gestion

PEGE

61, avenue de la Forêt Noire 67085 STRASBOURG Cedex

Tél. : (33) 0390242152

Fax : (33) 0390242064

www-ulp.u-strasbg.fr/large 


\title{
Collateral and Adverse Selection in Transition Countries
}

(April 2008)

\author{
Laurent Weill $^{1}$ \\ LARGE, Université Robert Schuman, Institut d'Etudes Politiques, \\ 47 avenue de la Forêt-Noire, 67082 Strasbourg Cedex, France.
}

\section{Christophe J. Godlewski ${ }^{2}$}

LARGE, Faculty of Business and Economics, Université Louis Pasteur,

61 avenue de la Forêt-Noire, 67085 Strasbourg Cedex, France.

\footnotetext{
1 Tel : 33-3-88-41-77-54 ; fax : 33-3-88-41-77-78; e-mail : laurent.weill@urs.u-strasbg.fr. Corresponding author.

${ }^{2}$ Tel : 33-3-90-24-21-21 ; fax : 33-3-90-24-20-64 ; e-mail : godlewski@cournot.u-strasbg.fr
} 


\title{
Collateral and Adverse Selection in Transition Countries
}

\begin{abstract}
:
This paper tackles the question of knowing whether collateral helps solve adverse selection problems in transition countries. We use a unique dataset of about 400 bank loans from 16 transition countries. Our findings support the view of a positive link between the presence of collateral and the risk premium, which is in accordance with the observed-risk hypothesis. This suggests that collateral does not mitigate adverse selection problems in transition countries.
\end{abstract}

Keywords: bank, collateral, transition economies.

JEL Classification: G21, P20. 


\section{Collateral and Adverse Selection in Transition Countries}

\section{Introduction}

There is a wide consensus regarding the problems of financing for companies in European transition economies. Central and Eastern Europe is the only area in the world where lack of financing is mentioned in the three main obstacles to business activity and company growth for small and medium-sized companies, as pointed out by Pissarides (1999). These difficulties notably result from the limited access to bank credit. A key issue for the access to credit is the availability of collateral. Indeed Bratkowski et al. (2000) mention that the probability of being granted a loan increases with the level of collateral offered by the firm in the Czech Republic, Hungary and Poland. In a similar vein, Dvorak (2004) points out that collateral requirement is the first obstacle in obtaining external financing for a sample of Czech companies.

But why are collaterals required by banks in transition countries? A first intuitive reason is the fact that collateral allows a reduction of the loan loss for the bank in the event of default. It can however also be argued that collateral helps solve the problems resulting from information asymmetries. Namely, it would help solve the problem of moral hazard after the loan is granted. Indeed collateral would have a binding role on the borrower which favours the alignment of his interests on the bank's. Furthermore, collateral would help solve the problem of adverse selection borne by the bank when lending, as it constitutes a signalling instrument providing the bank with some valuable information. Indeed, collateral helps the bank obtain private information owned by the borrower, as high-quality borrowers are more induced to 
accept to provide collateral in compensation of a low loan rate than low-quality borrowers are.

The aim of this paper is to test the relevance of this latter argument, namely the role of collateral to mitigate adverse selection problems in transition countries. As collateral requirements are presented to be a major obstacle to the access to credit, this is a key issue in the perspective of improving the access to credit for firms in transition countries. We do so by using a unique dataset of 391 bank loans from 16 transition countries extracted from Dealscan, which supplies detailed information on the presence of collateral and the risk premium. This dataset is exceptional in the sense that it provides information at the loan-level for a large sample of loans from different countries.

According to the adverse selection argument, we should observe a negative link between the presence of collateral and the risk premium. However there is a commonly accepted view among bankers that riskier loans would be associated with more collateral. The rationale is that banks would be able to sort the borrowers from information they have on their quality. As a result, they would charge riskier borrowers with higher loan rates and require higher collateral from these borrowers. In accordance with this view, the scarce papers on this link in developed countries all conclude to a positive relationship between collateral and risk premium (Berger and Udell, 1990, 1995; Blazy and Weill, 2005).

It is therefore of utmost interest to check the relevance of the role of collateral to solve adverse selection problems in transition countries. Indeed, the context of transition countries can be more appropriate for the emergence of the role of collateral to mitigate adverse selection (Allen and Gale, 2000; Llewellyn, 2002). These countries are characterized with short length of lending relationships and uncertain 
accounting information, both characteristics contributing to favour ex ante information asymmetries. In addition, there exist other means than collateral to solve adverse selection problems such as screening. However the efficiency of screening in banks from transition countries is likely to suffer from the lack of know-how of bank employees, owing to the short period of market economy in these countries. Therefore, one could expect that greater information asymmetries between the borrower and the lender in transition countries than in developed countries contribute to favour the relevance of adverse selection argument for the use of collateral in transition countries.

The paper is organized as follows. Section 2 presents the background on the role of collateral to mitigate adverse selection problems. Section 3 describes data and variables. In section 4, we develop the empirical results. We finally provide some concluding remarks in section 5.

\section{Background}

This section presents the literature on the adverse selection argument for the use of collateral. We first develop the theory underlying this argument, before presenting the empirical tests.

Collateral may solve the problem of adverse selection thanks to the better information owned by the borrower in comparison to the bank before the lending decision. This private information may lead to credit rationing because of the inability of the bank to price the loan according to the borrower's quality (Stiglitz and Weiss, 1981). Therefore, high-quality borrowers have incentives to show their quality, using a credible signal, meaning a signal that can not be provided by low-quality borrowers. 
Collateral is such a signal, as it is more costly for low-quality borrowers since they have a higher chance of defaulting and hence of losing the collateral (Bester, 1985; Chan and Kanatas, 1985; Besanko and Thakor, 1987). Consequently, as collateral acts as a signalling device, it conveys valuable information on the borrower to the bank, which can then screen borrowers by offering the choice between a secured loan with a low interest rate and an unsecured loan with a high interest rate. A high-quality borrower will be inclined to choose the loan with a collateral as its low risk of default means a low probability to lose collateral and a high probability to repay interest.

Therefore, this argument supports the view of a negative link between collateral and credit risk, as a secured loan would be associated with a higher quality of borrowers. However, the fact that collateral is associated with greater credit risk has gone mainstream among bankers as mentioned by Berger and Udell (1990) and Jimenez and Saurina (2004). The rationale underlying this argument is that banks can sort the borrowers from information they have on their quality. Consequently they charge riskier borrowers with higher rates, and simultaneously require more collateral from these borrowers to reduce loan loss in the event of default. Since collateral reduces its loss, the bank would be more inclined ceteris paribus to ask collateral from borrowers with a higher credit risk. This argument is commonly called the observedrisk hypothesis.

The existence of such an opposite hypothesis to the adverse selection argument makes of utmost interest the empirical tests on the link between collateral and risk premium. Therefore, we now tackle the question of knowing whether the selection adverse argument for the use of collateral is empirically validated.

Empirical literature remains however relatively scarce on this issue. Berger and Udell (1990) investigate the relationship between collateral and credit risk on a 
sample of 1 million loans from US banks. They notably test the hypothesis that adverse selection matters for the use of collateral by regressing the risk premium on a set of loan characteristics including a dummy variable considering whether the loan is secured or not. The conclusion does not corroborate the adverse selection argument, as a positive and significant relationship is observed between collateral and risk premium. This finding may be explained by the fact that banks require more collateral from riskier borrowers who are also charged with higher loan rates, in accordance with the observed-risk hypothesis.

Jimenez and Saurina (2004) focus on the determinants of the probability of default of bank loans on a wide set of 3 million loans provided by Spanish banks. Probability of default is considered as an ex post credit risk measure. As a consequence, they do not only test whether collateral mitigates adverse selection problems, but also whether collateral solves moral hazard problems. According to this latter argument, the presence of collateral should solve the problems of moral hazard after the loan is granted, as the borrower would be more inclined to take the optimal decisions owing to the alignment of his interests on the bank's. The probability of default is explained by a set of loan characteristics including some information on the collateral. Three dummy variables depending on the collateralized share of the loan are jointly taken into account in the model. They find a greater probability of default for secured loans.

Blazy and Weill (2005) extend the analysis by investigating the influence of the collateral type and value, taking into consideration that all types of collateral may not be equivalent for banks. They use a dataset of 735 bank loans on French distressed firms with full information on collateral. They test the three theoretical reasons for the use of collateral by banks (reduction of loan loss in the event of default, adverse 
selection, and moral hazard). Regarding adverse selection, they analyze the link between collateral and risk premium, by checking whether the type and the value of collaterals exert an influence on the relationship. They observe first a positive relationship between the presence of collateral and the risk premium. The inclusion of type and value of collaterals is done by including six variables aggregating collateral value according to a classification in six types of collaterals in the regressors of the risk premium. They find out that no collateral variable is negatively linked with the risk premium, while three types of collateral among the six tested are significantly positive, the three other being not significant. Consequently, this study also tends to reject the adverse selection argument for the use of collateral.

Berger and Udell (1995) analyze a closely related issue: the role of banking relationships on loan characteristics. They investigate the associations among collateral, banking relationship and risk premium on a sample of 1 million loans from US banks. It provides some support on the positive association between collateral and risk premium, and clear evidence that firms with longer banking relationships are less likely to pledge collateral. Consequently, this work tends to support the view that collateral is associated with greater risk. On this issue of relationship lending, Harhoff and Körting (1998) conclude similarly on 994 loans from German banks, while Degryse and van Cayseele (2000)'s work on 18000 loans from Belgian banks provides mixed evidence on this issue.

Finally, the recent study from Jimenez et al. (2006) takes a broader perspective by analyzing a wide range of determinants of the presence of collateral. Tested determinants include the characteristics of the borrower with credit quality, but also the characteristics of the lender, the competition on the loan market and the macroeconomic conditions. Credit quality is related to the theories of the use of 
collateral by banks. It is proxied by a dummy variable taking into account the fact that the borrower had recently a loan in default. The authors then observe that the credit quality of the borrower is the main determinant of the use of collateral.

This presentation of the literature devoted to the adverse selection argument for the use of collateral leads to two main conclusions. First, empirical evidence is rather in favour of the observed-risk hypothesis according to which riskier borrowers are required to provide more often collateral, in accordance with the common opinion of bankers. This element tends to invalidate the theoretical argument on the use of collateral dealing with resolution adverse selection problems. Second, studies remain very scarce and are limited to a couple of Western countries. Therefore, no study testing this possible role of collateral has ever been performed in transition countries, whereas their specific framework might influence the use of collateral to mitigate adverse selection problems. Our empirical work aims at filling this loophole.

\section{Data and variables}

We collect a sample of 391 loans from the database from the Loan Pricing's Corporation's (Reuters) Dealscan database. This database provides detailed information on loans to large corporations. Loans come from 16 transition countries, including 11 Central and Eastern European countries (Bulgaria, Croatia, Czech Republic, Estonia, Hungary, Lithuania, Macedonia, Poland, Romania, Slovakia, Slovenia) and 5 countries from the Commonwealth of Independent States (Azerbaijan, Kazakhstan, Russia, Ukraine, Uzbekistan). Loans were granted between January 1996 and August 2006. 
We focus on the relationship between the presence of collateral and the risk premium. In this aim, we proceed to regressions of the risk premium on a set of variables including the presence of collateral and some control variables.

Risk premium is the difference between the loan rate and the prime rate used by the lender for the loan pricing. Information on risk premium is directly provided in the database. The presence of collateral is measured by a dummy variable (Collateral) equal to one whether the loan is secured or to zero else, following most works on the use of collateral.

We include three control variables in the estimations. We first take information on loan maturity into account (Maturity). The second control variable informs on the loan type through a dummy variable equal to one whether the loan is a term loan or to zero else (Type). A term loan is defined in Dealscan as an installment loan where amounts repaid may not be reborrowed. Finally, we control for loan size, which is the amount of the tranche of the loan (LoanAmount). Indeed syndicated loans are granted by tranches, which can be charged with different loan rates. Dummy variables for each country and each year are also included in the estimations to control for country effects and year effects.

Descriptive statistics are displayed in table 1 . We observe that a majority of loans is secured (59.85 per cent). This figure is in accordance with the shares of secured loans in total loans observed in studies on Western European countries. Berger and Udell (1995) observe that 53 per cent of firm loans are secured in their US sample, while Blazy and Weill (2005) point out a share of 74.5 per cent of secured loans for their sample of loans to distressed companies. However, one has to keep in mind that our sample includes only large loans to large companies, which are expected to have a lower default risk than other companies. 
The average risk premium is 244.80 basis points. It has to be stressed that this margin is observed on large loans, as the mean loan amount is 255.63 million dollars. However large loans are generally expected to be granted with low loan rates, owing to greater competition on loan rates. This latter point suggests high margins on loans in transition countries (Gadanecz, 2004). Loan amounts are as expected large on average, owing to the contents of the Dealscan database. The maturity of loans is relatively short with a mean of 41.6 months. This is in accordance with the observation in transition countries that most loans are granted on a short-term basis. Finally, a slight majority of loans are term loans (53.71 per cent).

\section{INSERT TABLE 1 HERE}

Table 2 summarises our sample structure, according to the country and the year. A notable remark is the fact that a majority of loans is originated from Russia (69 per cent). The breakdown by year shows an increasing number of loans with time, in accordance with the expansion of large loans in transition countries (Gadanecz, 2004). ${ }^{3}$

\section{INSERT TABLE 2 HERE}

\section{Results}

This section displays the findings on the role of collateral to solve adverse selection problems in transition countries. Theoretical literature suggests that

\footnotetext{
${ }^{3}$ The smaller number of loans for 2006 in comparison to 2004 and 2005 is due to the fact that we only have loans for 2006 from January to August.
} 
collateral may constitute a signalling instrument and consequently may help the bank obtain private information owned by the borrower. According to this argument, we should observe a negative link between the presence of collateral and the risk premium, as high-quality firms would be inclined to provide a collateral in exchange of a lower risk premium.

To test this hypothesis, we perform the regression of the risk premium on a set of variables including the dummy variable for the presence of collateral. Three estimations are computed. The first one is done on all countries. As a large proportion of loans come from Russia, we perform a second estimation specifically on Russia and a third estimation on loans granted to borrowers from CEE countries. ${ }^{4}$ These estimations allow us furthermore to investigate whether there exist some differences between Russia and CEE countries.

The results of the estimations are displayed in table 3. The fit of the regressions is satisfactory with adjusted $\mathrm{R}^{2}$ ranging between 0.0912 and 0.3810 . Our major finding is the positive and significant coefficient of Collateral in all estimations. Therefore, we observe that risk premium increases when the loan is secured. This evidence does not support the theoretical argument according to which collateral helps solve the problem of adverse selection. In contrast, it corroborates the observedrisk hypothesis according to which banks would ask for more collateral from riskier companies, which are already charged with higher loan rates. We then support the empirical evidence provided by Berger and Udell (1990), who also observe a positive link between the presence of collateral and risk premium on US loans.

\section{INSERT TABLE 3 HERE}

\footnotetext{
${ }^{4}$ There are not enough loans granted to borrowers from CIS countries other than Russia for a specific estimation on these countries.
} 
Turning to the control variables, we observe a negative and significant coefficient for LoanAmount in estimations for all countries and for Russia. This supports the view that greater loans are charged with lower loan margins. This finding is consistently found in the literature (e.g. Berger and Udell, 1990). It can result either from the existence of economies of scale in lending, or from the fact that larger borrowers are considered as safer customers. The only other significant control variable is Type, which is positive in the estimation for Russia. This suggests that term loans are charged with higher margins than other loans in Russia. This is not a surprising result, as term loans can be considered as riskier than other loans owing to the stronger commitment it represents for the lender. The last control variable, Maturity, is not significant in all three regressions. One could have expected a positive link between the maturity of the loan and the risk premium, as a greater maturity is generally associated with a higher risk and therefore with a higher risk premium. A possible explanation is the relatively low variance of the maturity of the loan. Indeed 90 per cent of the loans in our sample have maturity ranging from 1 to 5 years. This relatively low range of maturities may limit the differentiation in risk premium for the loans.

As great differences between countries can be observed in terms of creditor rights of access to the assets put up as collateral, a potential criticism to our estimations may be the fact that a cross-country investigation ignores these differences. To solve this concern, two possibilities exist. The first one is to replace cross-country estimations by single-country estimations. However, single-country estimations are not possible in our framework as national samples are small, with the notable exception of the Russian sample. It must nevertheless be stressed that the test 
performed on the Russian sample confirms our main findings. Therefore this test is a first answer to the potential problem of cross-country differences in creditor rights. The second one consists in including country-level variables taking into account creditor rights of access to the assets put up as collateral in the tests. Therefore, crosscountry differences in creditor rights are controlled in our regressions. In this aim, we perform two new estimations on our sample of all countries. We add alternatively two variables to the set of explaining variables in our model. Both come from the dataset developed by Djankov, McLiesh and Shleifer (2007). The first variable, Creditor, is an index aggregating four aspects of creditor rights. It ranges from 0 (weak creditor rights) to 4 (strong creditor rights). The second variable, Contract, is the number of days to resolve a payment dispute through courts. It measures the number of days it takes to enforce a simple debt contract, and therefore informs on the quality of law enforcement.

The estimations with these legal variables are presented in table $4 .{ }^{5}$ We observe that the inclusion of the legal variables does not change the results. Indeed the variable Collateral keeps a positive and strongly significant coefficient. Furthermore the coefficients for other variables also have the same sign and significance. Therefore, the positive and significant effect of Collateral is robust to the inclusion of differences in terms of creditor rights and of law enforcement for the access to the assets put up as collateral. ${ }^{6}$

\footnotetext{
${ }^{5}$ We exclude Estonia from the sample in these additional estimations, as we have no information on legal variables for Estonia in the dataset developed by Djankov, McLiesh and Shleifer (2007).

${ }^{6}$ As reported by Spamman (2006) for La Porta et al. (1998)'s shareholder protection index, some measures of legal environment might suffer from inconsistency or coding. However, as Spamman (2006) pointed it out, his results regarding the shareholder protection index can not be generalized to legal data in other studies, including Djankov, McLiesh and Shleifer (2007) from which we obtain information for Creditor and Contract variables. Furthermore, we do not include measures of shareholder protection in our estimations. Therefore, our conclusions should not be exposed to his criticisms.
} 


\section{INSERT TABLE 4 HERE}

Consequently, our tests do not support the view that collateral helps mitigate adverse selection in transition countries. This finding is observed in CEE countries and Russia taken separately. It is in accordance with the results obtained in developed countries by notably Berger and Udell (1990) for US loans or Blazy and Weill (2005) for French loans.

Following these latter studies, we provide evidence in favour of the observedrisk hypothesis according to which banks charge greater loan rates and ask for collateral to riskier companies.

However a key difference is that our findings are obtained in transition countries where the institutional context and the development of the banking industry are undoubtedly different. Namely, we could have expected that adverse selection hypothesis would gain more support in transition countries than in developed countries because of the greater information asymmetries between the borrower and the lender in these latter countries. Indeed, the length of the relationship between the borrower and the lender which contributes to reduce ex ante information asymmetries is shorter on average in transition countries than in developed countries, owing to their short history in market economy ${ }^{7}$. Furthermore, the efficiency of screening, which constitutes an alternative means to solve adverse selection problems, is expected to be lower in transition countries owing to the weaker know-how of bank employees, which may also be the result of a short period of market economy.

\footnotetext{
${ }^{7}$ One might argue that in transition economies lender-borrower relationship history might be longer due to the fact that many firms and banks are former SOEs and state banks. Such claim would hold if the majority of lender-borrower pairs are from the same country (i.e. lender and borrower have the same nationality). In our sample, only $5.9 \%$ of the lenders per deal are from the same country as the borrower. Therefore, we can consider that the history of relationship between lenders and borrowers is short for the vast majority of the loans in our sample.
} 
Nonetheless, the observed-risk hypothesis is also supported in transition countries, relative to the adverse selection hypothesis. This finding suggests that even in transition countries in which information asymmetries could be expected to be stronger than in developed countries, banks are able to sort the borrowers from information they have on their quality. Therefore, even in these countries, banks are able to charge the riskier companies with greater loan rates and a more frequent collateral requirement.

\section{Concluding remarks}

This research has analyzed empirically whether the presence of collateral contributes to mitigate adverse selection problems in transition countries. This argument has been theoretically developed in the literature to explain the widespread use of collateral (Bester, 1985; Chan and Kanatas, 1985; Besanko and Thakor, 1987). It has however not received empirical support in developed countries. One can therefore wonder whether this argument could be supported in the specific framework of transition countries in which ex ante information asymmetries may be exacerbated.

In this aim, we have investigated the link between the presence of collateral and the risk premium on a sample of about 400 loans from 16 transition countries. Our conclusion clearly rejects the argument that collateral is used in transition countries to solve adverse selection problems. Indeed we observe a positive relationship between the presence of collateral and the risk premium, in opposition with the argument of the collateral as a signalling instrument. This finding is however in accordance with the observed-risk hypothesis, according to which banks would be able to sort borrowers from information they have on quality. It is of greatest interest to observe 
that our results are in accordance with former studies on developed countries which all find out a positive link between collateral and risk premium.

As the resolution of adverse selection problems does not seem to be a satisfactory motivation for the widespread use of collateral, one should test the relevance of both other motives for the use of collateral, the reduction of the loan loss in the event of default and the resolution of moral hazard problems in transition countries. It would notably be of interest to know whether these motives play a more significant role in transition countries than in developed countries. 


\section{REFERENCES}

Allen, F., and D. Gale. 2000. Comparing Financial Systems. MIT Press.

Berger, A., and G. Udell. 1990. “Collateral, Loan Quality, and Bank Risk.” Journal of Monetary Economics, 25: 21-42.

Berger, A., and G. Udell. 1995. "Relationship Lending and Lines of Credit in Small Firm Finance”, Journal of Business, 68: 351-382.

Besanko, D., and A. Thakor. 1987. “Collateral and Rationing: Sorting Equilibria in Monopolistic and Competitive Credit Markets.” International Economic Review, 28: 671-689.

Bester, H. 1985. "Screening vs. Rationing in Credit Markets with Imperfect Information”, American Economic Review, 25: 21-42.

Blazy, R., and L. Weill. 2005. "Why Do Banks Ask for Collateral?" Presentation at the Northern Finance Conference, Vancouver.

Bratkowski, A., Grosfeld, I. and J. Rostowski. 2000. “Investment and Finance in De Novo Private Firms: Empirical Results from the Czech Republic, Hungary, Poland.” Economics of Transition, 8 (1): 101-116.

Chan, Y., and G. Kanatas. 1985. "Asymmetric Valuation and the Role of Collateral in Loan Agreements.” Journal of Money, Credit and Banking, 17: 85-95.

Degryse, H. and P. van Cayseele. 2000. “Relationship Lending Within a BankBased System: Evidence from European Small Business Data.” Journal of Financial Intermediation, 9: 90-109.

Djankov, S., McLiesh, C., and A. Shleifer. 2007. "Private Credit in 129 Countries.” Journal of Financial Economics, 84: 299-329. 
Dvorak, V. 2004. "Financing of Companies in the Czech Republic”, in M. Mejstrik (editor), Financial Markets in the Czech Republic, p. 259-285, Charles University in Prague, Karolinum Press.

Gadanecz, B. 2004. “The Syndicated Loan Market: Structure, Development and Implications.” BIS Quarterly Review, 75-89.

Harhoff, D., and T. Körting. 1998. "Lending Relationships in Germany Empirical Evidence from Survey Data.” Journal of Banking and Finance, 22: 13171353.

Jimenez, G., Salas, V., and J. Saurina. 2006. “Determinants of Collateral.” Journal of Financial Economics, 81: 255-281.

Jimenez, G., and J. Saurina. 2004. “Collateral, Type of Lender and Relationship Banking as Determinants of Credit Risk.” Journal of Banking and Finance, 28: 21912212.

La Porta, R., Lopez-de-Silanes, F., Shleifer, A., and Vishny, R. 1998. “Law and Finance.” Journal of Political Economy, 106: 1113-1155.

Llewellyn, D. 2002. “An Analysis of the Causes of Recent Banking Crises.”, European Journal of Finance, 8: 152-175.

Pissarides, F. 1999. “Is Lack of Funds The Main Obstacle of Growth? EBRD’s Experience with Small- and Medium-Sized Businesses in Central and Eastern Europe.” Journal of Business Venturing, 14: 519-539.

Spamann, H. 2006. "On the Insignificance and/or Endogeneity of La Porta et al.’s ‘Antidirector Rights Index’ under Consistent Coding.” Harvard Law School John M. Olin Center Discussion Paper nº , March 2006.

Stiglitz, J., and A. Weiss. 1981. "Credit Rationing in Markets with Imperfect Information.” American Economic Review, 71: 393-410. 
Table 1: Descriptive statistics

\begin{tabular}{lcccc}
\hline & Mean & Std Dev. & Min. & Max. \\
\hline Collateral (in \%) & 59.85 & 49.08 & 0 & 1 \\
Risk premium (in basis points) & 244.80 & 162.78 & 11.75 & 1037.50 \\
Maturity (in months) & 41.63 & 34.61 & 4 & 216 \\
LoanAmount (in million USD) & 255.63 & 821.70 & 6.00 & $13,391.00$ \\
Type (in \%) & 53.71 & 49.93 & 0 & 1 \\
\hline
\end{tabular}


Table 2 : Sample by country and by year

\begin{tabular}{|lc|cc|}
\hline Country & Number of loans & Year & Number of loans \\
\hline Azerbaïdjan & 1 & 1996 & 12 \\
Bulgaria & 2 & 1997 & 39 \\
Croatia & 8 & 1998 & 11 \\
Czech Republic & 7 & 1999 & 23 \\
Estonia & 2 & 2000 & 10 \\
Hungary & 21 & 2001 & 25 \\
Kazakhstan & 15 & 2002 & 28 \\
Lithuania & 3 & 2003 & 45 \\
Macedonia & 1 & 2004 & 56 \\
Poland & 24 & 2005 & 97 \\
Romania & 13 & 2006 & 45 \\
Russia & 272 & & \\
Slovakia & 13 & & \\
Slovenia & 7 & & \\
Ukraine & 4 & & \\
Uzbekistan & 1 & & \\
\hline
\end{tabular}


Table 3: Collateral and risk premium

\begin{tabular}{lccc}
\hline & $\begin{array}{c}\text { Estimation (1) } \\
\text { All countries }\end{array}$ & $\begin{array}{c}\text { Estimation (2) } \\
\text { Russia }\end{array}$ & $\begin{array}{c}\text { Estimation (3) } \\
\text { CEE countries }\end{array}$ \\
\hline Intercept & $1243.165^{* * *}$ & $1358.261^{* * *}$ & $496.364^{*}$ \\
Collateral & $(7.16)$ & $(10.69)$ & $(1.68)$ \\
& $47.844^{* * *}$ & $55.383^{* * *}$ & $70.692^{*}$ \\
Maturity & $(2.88)$ & $(2.99)$ & $(1.86)$ \\
& $0.962 \mathrm{E}-3$ & -0.262 & -0.096 \\
LoanAmount & $(0.01)$ & $(-0.70)$ & $(-0.31)$ \\
& $-44.103^{* * *}$ & $-54.317^{* * *}$ & -4.671 \\
Type & $(-7.04)$ & $(-7.79)$ & $(-0.29)$ \\
& 14.064 & $35.859^{* *}$ & -25.796 \\
Adjusted $\mathrm{R}^{2}$ & $(1.00)$ & $(2.24)$ & $(-0.85)$ \\
$\mathrm{N}$ & 0.3781 & 0.3810 & 0.0912 \\
& 391 & 270 & 100 \\
\hline
\end{tabular}

Dependent variable is the risk premium. t-statistic is in brackets. ${ }^{*},{ }^{* *}, * * *$ denote an estimate significantly different from 0 at the $10 \%, 5 \%$ or $1 \%$ level. Dummy variables for countries and years are not reported. 
Table 4: Collateral and risk premium: estimations with legal variables

\begin{tabular}{|c|c|c|}
\hline & $\begin{array}{c}\text { Estimation (1.1) } \\
\text { With Creditor Rights }\end{array}$ & $\begin{array}{c}\text { Estimation (1.2) } \\
\text { With Contract }\end{array}$ \\
\hline Intercept & $\begin{array}{c}1536.299 * * * \\
\quad(3.18)\end{array}$ & $\begin{array}{c}708.103 \\
(1.18)\end{array}$ \\
\hline Collateral & $\begin{array}{c}47.508^{* * *} \\
(2.87)\end{array}$ & $\begin{array}{c}47.508^{* * *} \\
(2.87)\end{array}$ \\
\hline Maturity & $\begin{array}{c}-0.109 \mathrm{E}-3 \\
(0.01)\end{array}$ & $\begin{array}{c}-0.109 \mathrm{E}-3 \\
(0.01)\end{array}$ \\
\hline LoanAmount & $\begin{array}{c}-44.080^{* * *} \\
(7.02)\end{array}$ & $\begin{array}{c}-44.080^{* * *} \\
(7.02)\end{array}$ \\
\hline Type & $\begin{array}{l}14.066 \\
(0.99)\end{array}$ & $\begin{array}{l}14.066 \\
(0.99)\end{array}$ \\
\hline Creditor rights & $\begin{array}{c}-146.751 \\
(0.80)\end{array}$ & - \\
\hline Contract & - & $\begin{array}{l}1.453 \\
(0.80)\end{array}$ \\
\hline Adjusted R² & 0.3793 & 0.3793 \\
\hline $\mathrm{N}$ & 389 & 389 \\
\hline
\end{tabular}




\section{PAPIERS}

\section{Laboratoire de Recherche en Gestion \& Economie (LARGE)}

D.R. $n^{\circ} 1$ "Bertrand Oligopoly with decreasing returns to scale", J. Thépot, décembre 1993

D.R. $\mathrm{n}^{\circ} 2$ "Sur quelques méthodes d'estimation directe de la structure par terme des taux d'intérêt", P. Roger - N. Rossiensky, janvier 1994

D.R. $n^{\circ} 3$ "Towards a Monopoly Theory in a Managerial Perspective", J. Thépot, mai 1993

D.R. n 4 "Bounded Rationality in Microeconomics", J. Thépot, mai 1993

D.R. n 5 "Apprentissage Théorique et Expérience Professionnelle", J. Thépot, décembre 1993

D.R. $n^{\circ} 6 \quad$ "Stratégic Consumers in a Duable-Goods Monopoly", J. Thépot, avril 1994

D.R. n 7 "Vendre ou louer ; un apport de la théorie des jeux", J. Thépot, avril 1994

D.R. $n^{\circ} 8$ "Default Risk Insurance and Incomplete Markets", Ph. Artzner - FF. Delbaen, juin 1994

D.R. n 9 "Les actions à réinvestissement optionnel du dividende", C. Marie-Jeanne - P. Roger, janvier 1995

D.R. $\mathrm{n}^{\circ} 10 \quad$ "Forme optimale des contrats d'assurance en présence de coûts administratifs pour l'assureur", S. Spaeter, février 1995

D.R. n 11 "Une procédure de codage numérique des articles", J. Jeunet, février 1995

D.R. $n^{\circ} 12$ Stabilité d'un diagnostic concurrentiel fondé sur une approche markovienne du comportement de rachat du consommateur", N. Schall, octobre 1995

D.R. $n^{\circ} 13$ "A direct proof of the coase conjecture", J. Thépot, octobre 1995

D.R. nº 14 "Invitation à la stratégie", J. Thépot, décembre 1995

D.R. n 15 "Charity and economic efficiency", J. Thépot, mai 1996 
D.R. $n^{\circ} 16$ "Princing anomalies in financial markets and non linear pricing rules", P. Roger, mars 1996

D.R. n 17 "Non linéarité des coûts de l'assureur, comportement de prudence de l'assuré et contrats optimaux", S. Spaeter, avril 1996

D.R. $n^{\circ} 18$ "La valeur ajoutée d'un partage de risque et l'optimum de Pareto : une note", L. Eeckhoudt - P. Roger, juin 1996

D.R. $\mathrm{n}^{\circ} 19$ "Evaluation of Lot-Sizing Techniques : A robustess and Cost Effectiveness Analysis", J. Jeunet, mars 1996

D.R. n 20 "Entry accommodation with idle capacity", J. Thépot, septembre 1996

D.R. n 21 "Différences culturelles et satisfaction des vendeurs : Une comparaison internationale", E. Vauquois-Mathevet - J.Cl. Usunier, novembre 1996

D.R. $\mathrm{n}^{\circ} 22$ "Evaluation des obligations convertibles et options d'échange", A. Schmitt - F. Home, décembre 1996

D.R n 23 "Réduction d'un programme d'optimisation globale des coûts et diminution du temps de calcul, J. Jeunet, décembre 1996

D.R. $n^{\circ} 24$ "Incertitude, vérifiabilité et observabilité : Une relecture de la théorie de l'agence", J. Thépot, janvier 1997

D.R. $\mathrm{n}^{\circ} 25$ "Financement par augmentation de capital avec asymétrie d'information : l'apport du paiement du dividende en actions", C. Marie-Jeanne, février 1997

D.R. $\mathrm{n}^{\circ} 26$ "Paiement du dividende en actions et théorie du signal", C. Marie-Jeanne, février 1997

D.R. n 27 "Risk aversion and the bid-ask spread", L. Eeckhoudt - P. Roger, avril 1997

D.R. $n^{\circ} 28$ "De l'utilité de la contrainte d'assurance dans les modèles à un risque et à deux risques", S. Spaeter, septembre 1997

D.R. $n^{\circ} 29$ "Robustness and cost-effectiveness of lot-sizing techniques under revised demand forecasts", J. Jeunet, juillet 1997

D.R. $n^{\circ} 30$ "Efficience du marché et comparaison de produits à l'aide des méthodes d'enveloppe (Data envelopment analysis)", S. Chabi, septembre 1997

D.R. n 31 "Qualités de la main-d'œuvre et subventions à l'emploi : Approche microéconomique", J. Calaza - P. Roger, février 1998

D.R n 32 "Probabilité de défaut et spread de taux : Etude empirique du marché français", M. Merli - P. Roger, février 1998

D.R. n 33 "Confiance et Performance : La thèse de Fukuyama", 


\section{J.Cl. Usunier - P. Roger, avril 1998}

D.R. $n^{\circ} 34$ "Measuring the performance of lot-sizing techniques in uncertain environments", J. Jeunet - N. Jonard, janvier 1998

D.R. n 35 "Mobilité et décison de consommation : premiers résultas dans un cadre monopolistique", Ph. Lapp, octobre 1998

D.R. $\mathrm{n}^{\circ} 36$ "Impact du paiement du dividende en actions sur le transfert de richesse et la dilution du bénéfice par action", C. Marie-Jeanne, octobre 1998

D.R. n ${ }^{\circ} 37$ "Maximum resale-price-maintenance as Nash condition", J. Thépot, novembre 1998

D.R. $\mathrm{n}^{\circ} 38$ "Properties of bid and ask prices in the rank dependent expected utility model", P. Roger, décembre 1998

D.R. n 39 "Sur la structure par termes des spreads de défaut des obligations », Maxime Merli / Patrick Roger, septembre 1998

D.R. $n^{\circ} 40 \quad$ "Le risque de défaut des obligations : un modèle de défaut temporaire de l'émetteur", Maxime Merli, octobre 1998

D.R. n ${ }^{\circ} 41$ "The Economics of Doping in Sports", Nicolas Eber / Jacques Thépot, février 1999

D.R. $\mathrm{n}^{\circ} 42$ "Solving large unconstrained multilevel lot-sizing problems using a hybrid genetic algorithm", Jully Jeunet, mars 1999

D.R n 43 "Niveau général des taux et spreads de rendement", Maxime Merli, mars 1999

D.R. $\mathrm{n}^{\circ} 44$ "Doping in Sport and Competition Design", Nicolas Eber / Jacques Thépot, septembre 1999

D.R. n 45 "Interactions dans les canaux de distribution", Jacques Thépot, novembre 1999

D.R. n 46 "What sort of balanced scorecard for hospital", Thierry Nobre, novembre 1999

D.R. n 47 "Le contrôle de gestion dans les PME", Thierry Nobre, mars 2000

D.R. n ${ }^{\circ} 48$ "Stock timing using genetic algorithms", Jerzy Korczak - Patrick Roger, avril 2000

D.R. n 49 "On the long run risk in stocks : A west-side story", Patrick Roger, mai 2000

D.R. $\mathrm{n}^{\circ} 50$ "Estimation des coûts de transaction sur un marché gouverné par les ordres : Le cas des composantes du CAC40", Laurent Deville, avril 2001

D.R. $n^{\circ} 51$ "Sur une mesure d'efficience relative dans la théorie du portefeuille de Markowitz", Patrick Roger / Maxime Merli, septembre 2001 
D.R. $n^{\circ} 52$ "Impact de l'introduction du tracker Master Share CAC 40 sur la relation de parité callput", Laurent Deville, mars 2002

D.R. n 53 "Market-making, inventories and martingale pricing", Patrick Roger / Christian At / Laurent Flochel, mai 2002

D.R. $n^{\circ} 54$ "Tarification au coût complet en concurrence imparfaite", Jean-Luc Netzer / Jacques Thépot, juillet 2002

D.R. $n^{\circ} 55$ "Is time-diversification efficient for a loss averse investor ?", Patrick Roger, janvier 2003

D.R. $\mathrm{n}^{\circ} 56$ “Dégradations de notations du leader et effets de contagion”, Maxime Merli / Alain Schatt, avril 2003

D.R. n 57 “Subjective evaluation, ambiguity and relational contracts”, Brigitte Godbillon, juillet 2003

D.R. $n^{\circ} 58$ "A View of the European Union as an Evolving Country Portfolio", Pierre-Guillaume Méon / Laurent Weill, juillet 2003

D.R. n 59 “Can Mergers in Europe Help Banks Hedge Against Macroeconomic Risk ?”, Pierre-Guillaume Méon / Laurent Weill, septembre 2003

D.R. $n^{\circ} 60$ "Monetary policy in the presence of asymmetric wage indexation", Giuseppe Diana / Pierre-Guillaume Méon, juillet 2003

D.R. $n^{\circ} 61$ “Concurrence bancaire et taille des conventions de services”, Corentine Le Roy, novembre 2003

D.R. n 62 “Le petit monde du CAC 40”, Sylvie Chabi / Jérôme Maati

D.R. $n^{\circ} 63$ "Are Athletes Different? An Experimental Study Based on the Ultimatum Game”, Nicolas Eber / Marc Willinger

D.R. n 64 "Le rôle de l'environnement réglementaire, légal et institutionnel dans la défaillance des banques : Le cas des pays émergents”, Christophe Godlewski, janvier 2004

D.R. $n^{\circ} 65$ "Etude de la cohérence des ratings de banques avec la probabilité de défaillance bancaire dans les pays émergents”, Christophe Godlewski, Mars 2004

D.R. n 66 "Le comportement des étudiants sur le marché du téléphone mobile : Inertie, captivité ou fidélité ?”, Corentine Le Roy, Mai 2004

D.R. $n^{\circ} 67$ "Insurance and Financial Hedging of Oil Pollution Risks”, André Schmitt / Sandrine Spaeter, September, 2004

D.R. $\mathrm{n}^{\circ} 68$ "On the Backwardness in Macroeconomic Performance of European Socialist Economies”, Laurent Weill, September, 2004

D.R. $n^{\circ} 69$ "Majority voting with stochastic preferences: The whims of a committee are smaller than the whims of its members”, Pierre-Guillaume Méon, September, 2004 
D.R. $\mathrm{n}^{\circ} 70$ "Modélisation de la prévision de défaillance de la banque : Une application aux banques des pays émergents”, Christophe J. Godlewski, octobre 2004

D.R. $\mathrm{n}^{\circ} 71$ "Can bankruptcy law discriminate between heterogeneous firms when information is incomplete ? The case of legal sanctions", Régis Blazy, october 2004

D.R. n 72 “La performance économique et financière des jeunes entreprises”, Régis Blazy/Bertrand Chopard, octobre 2004

D.R. $\mathrm{n}^{\circ} 73$ "Ex Post Efficiency of bankruptcy procedures : A general normative framework”, Régis Blazy / Bertrand Chopard, novembre 2004

D.R. n 74 “Full cost pricing and organizational structure”, Jacques Thépot, décembre 2004

D.R. $\mathrm{n}^{\circ} 75$ "Prices as strategic substitutes in the Hotelling duopoly”, Jacques Thépot, décembre 2004

D.R. n 76 "Réflexions sur l'extension récente de la statistique de prix et de production à la santé et à l'enseignement”, Damien Broussolle, mars 2005

D. R. n 77 "Gestion du risque de crédit dans la banque : Information hard, information soft et manipulation ”, Brigitte Godbillon-Camus / Christophe J. Godlewski

D.R. n 78 "Which Optimal Design For LLDAs”, Marie Pfiffelmann

D.R. $\mathrm{n}^{\circ} 79$ “Jensen and Meckling 30 years after : A game theoretic view”, Jacques Thépot

D.R. n 80 “Organisation artistique et dépendance à l'égard des ressources”, Odile Paulus, novembre 2006

D.R. $n^{\circ} 81$ "Does collateral help mitigate adverse selection? A cross-country analysis”, Laurent Weill -Christophe J. Godlewski, novembre 2006

D.R. $\mathrm{n}^{\circ} 82$ "Why do banks ask for collateral and which ones ?”, Régis Blazy - Laurent Weill, décembre 2006

D.R. $n^{\circ} 83$ "The peace of work agreement : The emergence and enforcement of a swiss labour market institution”, D. Broussolle, janvier 2006.

D.R. $\mathrm{n}^{\circ} 84$ "The new approach to international trade in services in view of services specificities : Economic and regulation issues”, D. Broussolle, septembre 2006.

D.R. $n^{\circ} 85$ "Does the consciousness of the disposition effect increase the equity premium" ?, P. Roger, juin 2007

D.R. n 86 "Les déterminants de la décision de syndication bancaire en France”, Ch. J. Godlewski

D.R. n 87 “Syndicated loans in emerging markets”, Ch. J. Godlewski / L. Weill, mars 2007

D.R. $n^{\circ} 88$ "Hawks and loves in segmented markets : A formal approach to competitive 
aggressiveness”, Claude d'Aspremont / R. Dos Santos Ferreira / J. Thépot, mai 2007

D.R. n 89 “On the optimality of the full cost pricing”, J. Thépot, février 2007

D.R. n'90 "SME's main bank choice and organizational structure : Evidence from France”, H. El Hajj Chehade / L. Vigneron, octobre 2007

D.R n 91 “How to solve St Petersburg Paradox in Rank-Dependent Models” ?, M. Pfiffelmann, octobre 2007

D.R. $n^{\circ} 92$ "Full market opening in the postal services facing the social and territorial cohesion goal in France”, D. Broussolle, novembre 2007

D.R. $n^{\circ}$ 2008-01 A behavioural Approach to financial puzzles, M.H. Broihanne, M. Merli, P. Roger, janvier 2008

D.R. $\mathrm{n}^{\circ}$ 2008-02 What drives the arrangement timetable of bank loan syndication ?, Ch. J. Godlewski, février 2008

D.R. $n^{\circ}$ 2008-03 Financial intermediation and macroeconomic efficiency, Y. Kuhry, L. Weill, février 2008

D.R. $n^{\circ}$ 2008-04 The effects of concentration on competition and efficiency : Some evidence from the french audit market, G. Broye, L. Weill, février 2008

D.R. $\mathrm{n}^{\circ}$ 2008-05 Does financial intermediation matter for macroeconomic efficiency?, P.G. Méon, L. Weill, février 2008

D.R. $n^{\circ}$ 2008-06 Is corruption an efficient grease ?, P.G. Méon, L. Weill, février 2008

D.R. $\mathrm{n}^{\circ}$ 2008-07 Convergence in banking efficiency across european countries, L. Weill, février 2008

D.R. $\mathrm{n}^{\circ}$ 2008-08 Banking environment, agency costs, and loan syndication : A crosscountry analysis, Ch. J. Godlewski, mars 2008

D.R. $\mathrm{n}^{\circ}$ 2008-09 Are French individual investors reluctant to realize their losses ?, Sh. Boolell-Gunesh / M.H. Broihanne / M. Merli, avril 2008

D.R. $n^{\circ}$ 2008-10 Collateral and adverse selection in transition countries, Ch. J. Godlewski / L. Weill, avril 2008. 
